\title{
Sharp accumulation of heavy metals after weaning in the South American fur seal Arctocephalus australis
}

\author{
Marcela S. Gerpe ${ }^{1,2, *}$, Alberto Ponce de León ${ }^{4}$, Ricardo Bastida ${ }^{1,3}$, \\ Víctor J. Moreno ${ }^{2}$, Diego H. Rodríguez ${ }^{1,3}$ \\ ${ }^{1}$ Consejo Nacional de Investigaciones Científicas y Técnicas (CONICET), Argentina \\ ${ }^{2}$ Laboratorio de Ecotoxicología, and ${ }^{3}$ Laboratorio de Mamíferos Marinos, Departamento de Ciencias Marinas, FCEyN, \\ Universidad Nacional de Mar del Plata, Funes 3350, 7600 Mar del Plata, Argentina \\ ${ }^{4}$ Dirección Nacional de Recursos Acuáticos del Uruguay, Av. Constituyente 1497, 5to Piso, 11200, Montevideo, Uruguay
}

\begin{abstract}
In marine mammals, the transition period between lactation and independent feeding provides an opportunity to evaluate the influence of the first solid food on heavy metal concentrations in their tissues at early stages of their life cycle. The aim of the present study was to compare mercury, cadmium, zinc and copper levels in lactating and recently weaned South American fur seal Arctocephalus australis pups from Uruguay and northern Argentina, in order to evaluate the heavy metal intake through solid food shortly after weaning. Heavy metal concentrations in liver, muscle and kidney were determined by atomic absorption spectroscopy. Mercury levels in suckling pups reached up to 0.60 and $0.40 \mu \mathrm{g} \mathrm{g}^{-1}$ wet weight in liver and kidney tissues, respectively. This group presented lower levels of cadmium, with maximum concentrations of $0.11 \mathrm{\mu g} \mathrm{g}^{-1}$ and $0.17 \mathrm{\mu g} \mathrm{g}^{-1}$ in liver and kidney tissues, respectively. Weaned pups showed significantly higher levels of both cadmium (liver $=6.93 \pm 4.73 \mathrm{ug} \mathrm{g}^{-1}$; kidney $=20.89 \pm 5.00{\mu g^{-1}}^{-1}$ ) and mercury (liver $=3.91 \pm 1.16 \mu \mathrm{g} \mathrm{g}^{-1}$, kidney $=0.57 \pm 0.15 \mu \mathrm{g} \mathrm{g}^{-1}$ ). These significantly higher levels, and a clear distributional pattern between organs, strongly suggest a rapid intake of heavy metals during the first months after weaning. The presence of mercury and cadmium in weaned pups also indicates relevant early predation on fish and squid, representing a considerable contribution of both metals, but mainly cadmium, for South American fur seal pups. This sharp accumulation could be used as an indicator of the weaning process. Furthermore, heavy metal levels of pups would constitute a relevant baseline level in the early life of the South American fur seal.
\end{abstract}

KEY WORDS: Heavy metals • Accumulation · Suckling and weaned pups · Diet influence • South American fur seal

\section{INTRODUCTION}

Marine mammals occupy high positions in marine food webs and have a long lifespan. They have a high capacity to accumulate heavy metals in their tissues, particularly liver and kidney, whereas lead is specifically accumulated in hard tissue (bone and teeth) (Julshamn \& Grahl-Nielsen 2000, Gerpe et al. 2002, 2007, Law et al. 2003). Diet constitutes their main source of exposure, and tissue concentrations in seals are associated with specific food items and trophic position, age and size of the predator. In addition, some prey species present specific metal bioavailability, e.g. mercury for fish (Storelli et al. 2004) and cadmium for squid (Bustamante et al. 1998, Gerpe et al. 2000). The diet of South American fur seal Arctocephalus australis is dominated by fish and squid, with a minor presence of shrimp in northern Argentina and Uruguay (Vaz Ferreira \& Ponce de León 1987, Rodríguez 1996, Naya et al. 2002). South American fur seals exhibit prolonged lactation (circa 8 to $12 \mathrm{mo}$ ) characterized by progressive weaning (Vaz Ferreira \& Ponce de León 1987). During the final phase of lactation, pups gradually begin to take solid food; thus, an increase of heavy 
metal levels in their tissues during this period and the subsequent months of nutritional independence can be expected.

The aim of the present study was to compare mercury, cadmium, zinc and copper levels in lactating and recently weaned South American fur seal Arctocephalus australis pups from Uruguay and northern Argentina, in order to evaluate the heavy metal intake through solid food shortly after weaning.

\section{MATERIALS AND METHODS}

The study was performed in suckling (SP) and weaned (WP) South American fur seal Arctocephalus australis pups, born in the same breeding season (1987 to 1988 ; Table 1). Suckling pups $(\mathrm{n}=12)$ were sampled during a previous commercial harvest in Isla del Marco, Uruguay $\left(34^{\circ} 24^{\prime} 08^{\prime \prime} \mathrm{S}, 53^{\circ} 46^{\prime} 34^{\prime \prime} \mathrm{W}\right.$; Fig. 1). Weaned pups $(\mathrm{n}=11)$ were sampled from an anonymous intentional killing off Mar del Plata, Argentina $\left(37^{\circ} 30^{\prime} \mathrm{S}\right.$ to $38^{\circ} 30^{\prime} \mathrm{S}$; Fig. 1). Only fresh carcasses in good physical condition - based mainly on determination of the amount of subcutaneous blubber-were selected.

SP were classified as those with only milk in their stomachs and with no hard prey remains in the digestive tract; WP were classified as those with only hard prey remains in their digestive tract. Total length and sex were determined for each seal. Age was estimated in months from the sampling date (late September 1988 in SP and January to June 1989 in WP) to the mean pupping peak in Uruguayan colonies (last week of November to first week of December; Vaz Ferreira \& Ponce de León 1987). All the animals analyzed were younger than $24 \mathrm{mo}$, calculated from absolute agebody length curves determined by growth layer groups in canine teeth (Batallés et al. 1990).

Liver, kidney and muscle tissues were sampled and frozen at $-20^{\circ} \mathrm{C}$ until analyses. Metals were determined by atomic absorption spectroscopy, using a graphite furnace for cadmium, cold vapor for mercury and an air/acetylene flame for copper and zinc. Methodologies were according to Moreno et al. (1984) for mercury, the FAO/SIDA (1983) for copper and zinc, and the PAAR 00111 analytical method (Obras Sanitarias Sociedad de Estado, unpubl. data) for cadmium. Mineralization of samples was performed by acid digestion with nitric:sulphuric acids (4:1, for mercury), nitric:perchloric acids (3:1, for copper and zinc) and nitric acid (for cadmium). Analytical grade reagents and suprapure quality acids were used to prepare samples, blanks and calibration curves. Quality control was checked with analyses - under the same conditions as samples - of certified reference material
(LUTS-1, lobster hepatopancreas from the National Research Council of Canada, and No. 6 mussel from NIES, Tsukuba, Japan). The obtained values were in agreement with those certified $(\mathrm{p}<0.05)$.

Heavy metal levels are presented in $\mu g \mathrm{~g}^{-1}$ wet weight (WW). Detection limits were $0.10 \mu \mathrm{g} \mathrm{g}^{-1}$ for copper and zinc, $0.04 \mu \mathrm{g} \mathrm{g}^{-1}$ for mercury and $0.04 \mu \mathrm{g} \mathrm{g}^{-1}$ for cadmium. Statistical differences were tested for significance by Student's $t$ or Kolmogorov-Smirnoff tests, depending on homoscedasticity (tested by Levene and Brown-Forsythe tests).

To assess the degree of association among the heavy metal concentrations in different tissues of both pup groups, a multivariate principal component analysis (PCA) was performed. Statistica 6.0 software was used for statistical analyses.

\section{RESULTS}

Cadmium, mercury, zinc and copper levels found in all tissues of Arctocephalus australis WP were significantly higher than those present in SP, with the highest differences recorded in renal and hepatic cadmium

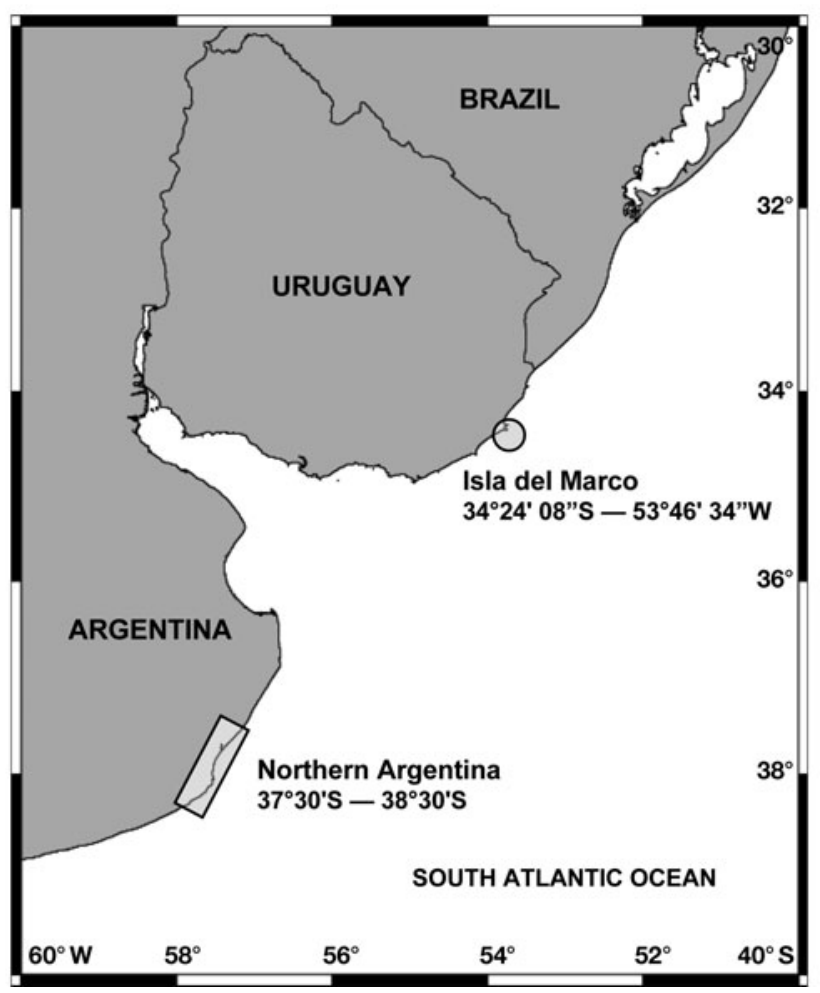

Fig. 1. Isla del Marco (Uruguay, 342 $24^{\prime} 08^{\prime \prime} \mathrm{S}, 53^{\circ} 46^{\prime} 34^{\prime \prime} \mathrm{W}$ ), where suckling South American fur seal Arctocephalus australis pups were commercially harvested (September 1988), and beaches in northern Argentina $\left(37^{\circ} 30^{\prime} \mathrm{S}\right.$ to $\left.38^{\circ} 30^{\prime} \mathrm{S}\right)$, where weaned pups were found intentionally killed (January to June 1989) 


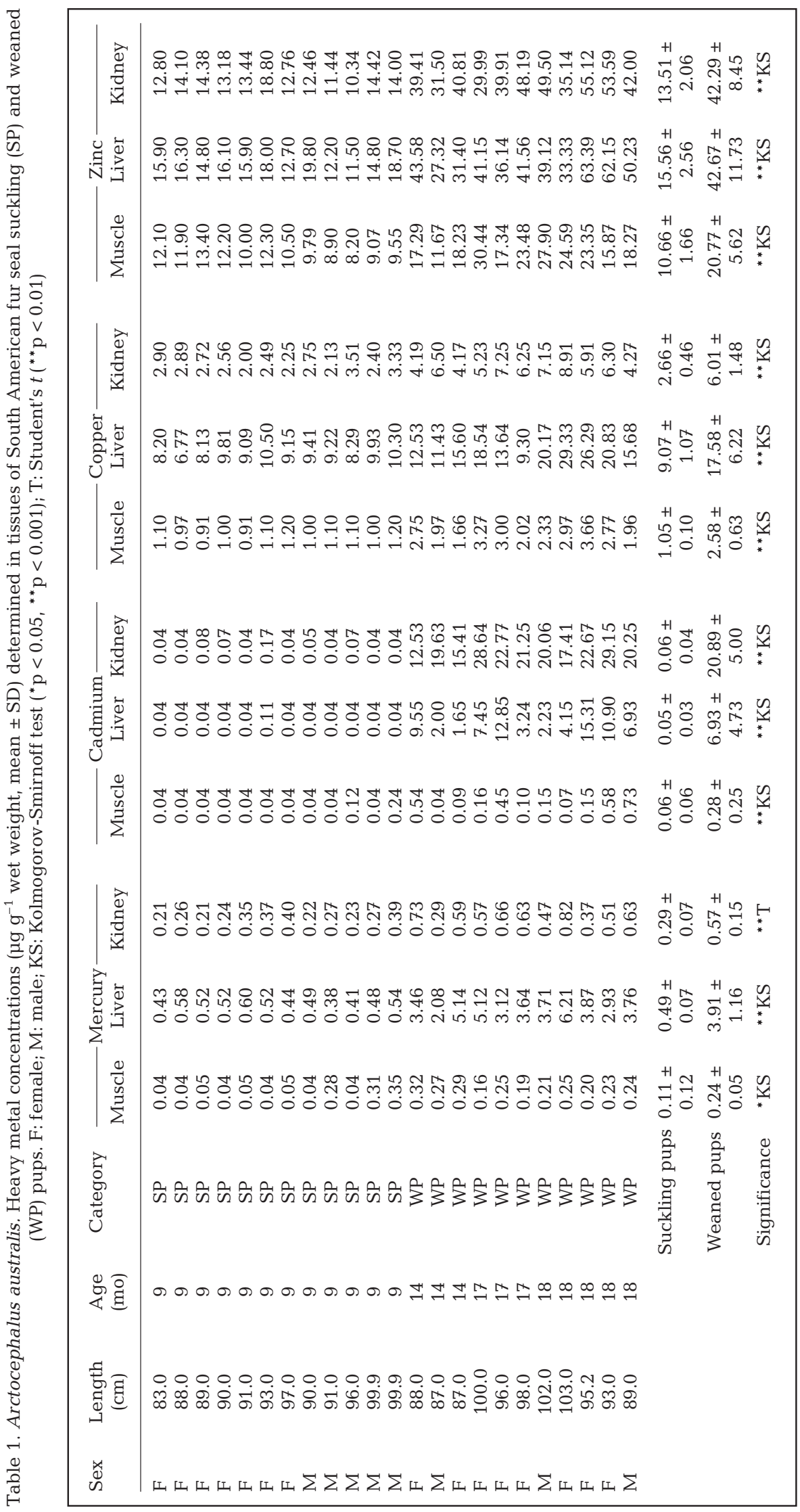

and mercury (Table 1). Both pup groups presented similar patterns of tissue distribution for mercury, copper and zinc, with differences between tissues more marked in the case of WP, where the heavy metal concentrations in liver and kidney were significantly higher in comparison to those in muscle $(p<0.01)$. Cadmium showed a similar distribution only in the case of $\mathrm{WP}$; all SP tissues presented concentrations within the same range.

In relation to metal distribution, each group presented a particular pattern: SP showed similar metallic distributions in the 3 analyzed tissues $(\mathrm{Zn}>\mathrm{Cu}>\mathrm{Hg}>\mathrm{Cd}$ ), whereas WP presented similar patterns for liver and muscle $(\mathrm{Zn}>\mathrm{Cu}>\mathrm{Cd}>$ $\mathrm{Hg}$ ), but a different pattern in kidney $(\mathrm{Zn}>\mathrm{Cd}>\mathrm{Cu}>\mathrm{Hg})$.

Mercury and cadmium concentrations showed a strong linear increase with age only in kidney and liver (Fig. 2A, B). Zinc and copper in both organs also showed an increase from SP to WP, although these increments were lower than those found for cadmium and mercury (Table 1).

The PCA revealed a strong relationship between heavy metal concentrations in the tissues analyzed. The correlation circle for these concentrations shows similar relative 'loadings' for each original variable on the first principal component, which is directly linked to the accumulation process (Fig. 3A). The first 2 dimensions of the PCA explain the structure of the data with very good classification, accounting for $80.5 \%$ of the total variability (Fig. 3B). PCA results clearly indicate 2 separate groupings of heavy metal values, corresponding to WP and SP. PC1 represented the major proportion of the variability $(>70 \%$ ) with SP presenting positive and WP presenting negative values of PC1. Negative values of PC1 and positive values of PC2 indicate those WP with the highest muscular values of mercury and cadmium. 

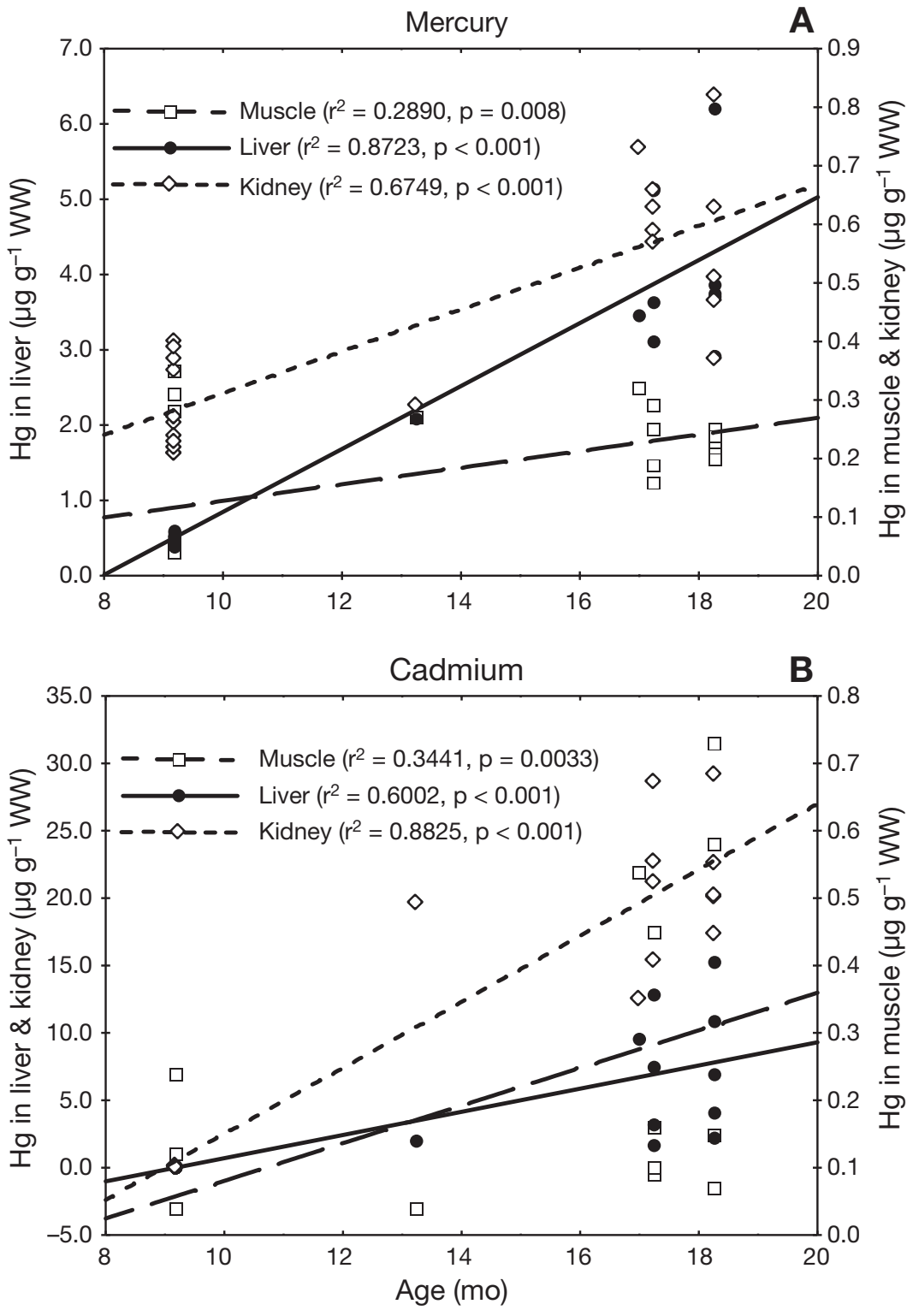

Fig. 2. Arctocephalus australis. Linear regression of (A) mercury and (B) cadmium in muscle (- - ), liver (-) and kidney (- - -) with age in South American fur seal pups. WW: wet weight

Placental transfer of methylated forms of mercury to fetuses has been reported for harp seals Pagophilus groenlandicus (Jones et al. 1976, Drescher et al. 1977, Wagemann et al. 1988) and other mammal species (Wolfe et al. 1998), and appears to be responsible for the initial fetal mercury burden found in several marine mammals. No evidence of placental transfer of cadmium has been found in South American fur seal pups, which is in agreement with previous results in several dolphin species (Honda \& Tatsukawa 1983, Law et al. 2003). Mercury transfer through the milk seems to be facilitated by both the presence of highly lipophilic methylated forms of the metal and the high lipid content of South American fur seal milk (28.3 to $57.1 \%$; Ponce de León \& Pin 2006).

A reduced transfer of cadmium during lactation is suggested by the low concentration found in SP. Detectable milk transfer of mercury and a very limited transfer of cadmium were also reported in harp seals Pagophilus groenlandicus (Jones et al. 1976, Wageman et al. 1988) and harbour seals Phoca vitulina (Drescher et al. 1977). The contrasting contribution of both metals via milk and placenta in South American fur seals is confirmed by the levels recorded in WP and SP. Moreover, these results indicate that cadmium may be present in South American fur seal mothers as a non-lipophilic chemical compound, or is present in such a low concentration that it is unavailable to be transferred.

Cephalopods are key species in the transfer of cadmium to top predators, such as marine mammals and birds

\section{DISCUSSION}

A sharp and rapid uptake of heavy metals shortly after weaning, particularly in the case of cadmium, was evident in South American fur seal Arctocephalus australis pups. The low levels of both non-essential metals presented in SP suggest a very low placental and/or milk transfer. The different order of magnitude of mercury levels in SP compared to those of cadmium is indicative that, in South American fur seals, mercury is transferred via the placenta at a higher rate than is cadmium.
(Bustamante et al. 1998, Aguiar dos Santos \& Haimovici 2001, Dorneles et al. 2007). They are also a main prey of South American fur seals in northern Argentina and Uruguay (Vaz Ferreira \& Ponce de León 1987, Naya et al. 2002, Bastida et al. 2007), particularly the Argentine short-fin squid Illex argentinus. Stomach content analysis of the studied WP revealed a frequency of occurrence (FO) of $100 \%$ of Argentine shortfin squid, followed by unidentified fish $(\mathrm{FO}=62.5 \%$ ), Argentine anchovies Engraulis anchoita $(\mathrm{FO}=25.0 \%)$, striped weakfish Cynoscion guatucupa $(\mathrm{FO}=23.0 \%)$ and toadfish Porichthys porossissimus $(\mathrm{FO}=12.5 \%)$ 


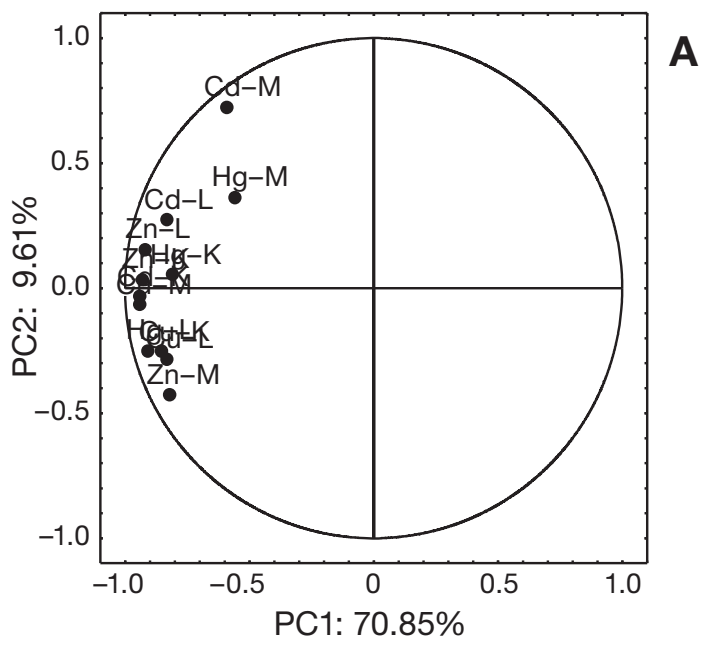

key role in the diet of this dolphin species (Gerpe et al. 2002, Rodríguez et al. 2002).

Cadmium showed a high accumulation rate even shortly after weaning. This is even more evident considering that the cadmium burden transferred from the mother (via the placenta or milk) was much lower than that of mercury. Although lower than cadmium levels, mercury levels showed a similar trend of accumulation from SP to WP, mainly in the liver.

The observed accumulation process of non-essential metals also suggests rapid assimilation since the beginning of solid feeding and a sharp transition from SP to WP. In addition, when heavy metal concentrations in WP are compared with those found in juvenile and adult South American fur seals from northern

B Argentina and Uruguay (mercury in liver: 20.4 to $33.0 \mu \mathrm{g} \mathrm{g}^{-1} \mathrm{WW}_{\text {; mercury }}$ in kidney: 0.8 to $1.3 \mu^{-1} \mathrm{~g}^{-1} \mathrm{WW}_{\text {; cad- }}$ mium in liver: 18.9 to $44.9 \mathrm{\mu g} \mathrm{g}^{-1} \mathrm{WW}_{\text {; }}$ cadmium in kidney: 40.7 to $71.0 \mu \mathrm{g} \mathrm{g}^{-1}$ WW; Gerpe 1990), it is evident that this first contribution of heavy metals constitutes an important baseline level in the following years.

The increases in copper and zinc from SP to WP-although lower than those manifested by non-essential metals-are associated with both higher assimilation from prey items and higher physiological requirements in WP. A major increment was expected, because at this developmental stage, high metabolic rates are associated with rapid growth, and zinc and copper are required for the proper physiological functioning of important enzymes. Higher levels in pups (SP and WP) and juveniles than in adults have previously been reported for different marine mammal species (Julshamn \& Grahl-Nielsen 2000), whereas Drescher et al. (1977) did not find this trend in harbour seals.

(Rodríguez 1996). Gerpe et al. (2000) found cadmium levels up to $270 \mathrm{\mu g} \mathrm{g}^{-1} \mathrm{WW}$ in the hepatopancreas of I. argentinus, indicating that this squid species could be a relevant source of cadmium for South American fur seals and other marine mammals, birds and fish in Argentine waters. The high cadmium concentrations found in WP liver and kidney confirm that squids is the main source of this metal for pups during the first phase of nutritional independence. A similar sharp increase was also confirmed in Franciscana dolphin Pontoporia blainvillei calves during the process of gradual weaning in the same area, where squid plays a
Liver and kidney proved to be the target organs for the concentration of both non-essential metals in the South American fur seal from an early age. Our results confirm that the pups are exposed to relatively high mercury and cadmium levels via their diet. This exposure leads to very high accumulation rates of these metals in their kidneys and liver shortly after weaning, which may have unknown physiological implications. Moreover, accumulation is remarkably fast, as liver and kidney levels reached up to $6.2 \mu \mathrm{g} \mathrm{g}^{-1}$ for mercury and $29.2 \mu \mathrm{g} \mathrm{g}^{-1}$ for cadmium, respectively, during the first 6 mo of nutritional independence. 
Both essential and non-essential heavy metals revealed a strong association among tissues, and PCA results confirmed a clear separation between WP and $\mathrm{SP}$ in close association with the accumulation process.

Fur seals distributed in northern Argentina correspond to the same genetic stock that breeds in Uruguay (Túnez et al. 2007), and the only difference influencing metal status was the solid diet in WP and, consequently, the metal contribution. Heavy metal accumulation is related to the intake of prey items; therefore, via placental transfer and milk, juveniles already have elevated levels of those metals, which may represent the baseline for tissue heavy metal burdens for their remaining lifespan.

\section{CONCLUSIONS}

A relevant increase in heavy metals, mainly mercury and cadmium, from SP to WP as a consequence of trophic independence was found in South American fur seals Arctocephalus australis. Cadmium levels are suggested to be directly related to the high contribution of squid in the diet, with no evidence of a significant maternal transfer through either the placenta or milk. Fish prey was identified as the main contributor to mercury accumulation, although maternal transfer also takes place. For cadmium, maternal transfer is negligible and accumulation occurs through squid as prey. This sharp accumulation could be used as an indicator of the weaning process. Furthermore, the heavy metal levels of pups may constitute a relevant baseline level for the early life of the South American fur seal.

Acknowledgements. The authors thank I. Ximenez (formerly of the Industria Lobera y Pesquera del Estado, Uruguay; ILPE) for tissue-sampling authorization during a commercial harvest at Isla del Marco. Sealing crews from ILPE kindly helped during fur seal necropsies in Uruguay. The present study was supported by grants from the Universidad Nacional de Mar del Plata (15/E005 and 15/E271) and the Agencia Nacional de Promoción Cientifica y Tecnológica (PICT97-00000-01651 and PICT99-0107111).

\section{LITERATURE CITED}

Aguiar dos Santos R, Haimovici M (2001) Cephalopods in the diet of marine mammals stranded or incidentally caught along southeastern and southern Brazil (21-34 $\left.{ }^{\circ} \mathrm{S}\right)$. Fish Res 52:99-112

Bastida R, Rodríguez D, Secchi E, da Silva V (2007) Mamíferos Acuáticos de Sudamérica y Antártida. Vazquez Mazzini Editores, Buenos Aires

Batallés LM, Pin O, Lima M (1990) Estudio del crecimiento del lobo fino Sudamericano (Arctocephalus australis) en Isla de Lobos, Uruguay. Frente Marítimo A 7:69-73

Bustamante P, Caurant F, Fowler SW, Miramand P (1998)
Cephalopods as a vector for the transfer of cadmium to top marine predators in the North-East Atlantic Ocean. Sci Total Environ 220:71-80

Dorneles PR, Lailson-Brito J, Aguiar dos Santos R, Silva da Costa PA, Malm O, Freitas Azevedo A, Machado Torres JP (2007) Cephalopods and cetaceans as indicators of offshore bioavailability of cadmium off Central South Brazil Bight. Environ Pollut 148:352-359

Drescher HE, Harms U, Huschenbeth E (1977) Organochlorines and heavy metals in the harbour seal Phoca vitulina from the German North Sea Coast. Mar Biol 41:99-106

FAO/SIDA (Food and Agriculture Organization/Styrelsen För Internationellt Utverklingssamarbete) (1983) Manual de métodos de investigación del medio ambiente acuático. Parte 9. Análisis de presencia de metales y organoclorados en los peces. FAO (Rome) Doc Téc Pes 212:1-35

Gerpe MS (1990) Distribución de metales traza, mercurio total, cadmio, cobre y zinc, en el lobo marino de dos pelos Sudamericano, Arctocephalus australis (Zimmerman, 1783). Tesis de Licenciatura, Universidad Nacional de Mar del Plata, Mar del Plata

> Gerpe MS, de Moreno JEA, Moreno VJ, Patat ML (2000) Cadmium, zinc and copper accumulation in the squid Illex argentinus from the Southwest Atlantic Ocean. Mar Biol 136:1039-1044

Gerpe MS, Rodríguez D, Moreno V, Bastida R (2002) Heavy metals in Franciscana dolphin, Pontoporia blainvillei. Latin Am J Aquat Mamm 1:95-106

Gerpe M, Rodríguez D, Moreno VJ, Bastida R, Aizpún J (2007) Copper, zinc, cadmium and mercury in southern sea lions (Otaria flavescens) from Argentina. Aquat Mamm 33:223-228

Honda K, Tatsukawa R (1983) Distribution of cadmium and zinc in tissues and organs, and their age-related changes in striped dolphins, Stenella coeruleoalba. Arch Environ Contam Toxicol 12:543-550

Jones D, Ronald K, Lavigne DM, Frank R, Holdrinet M, Uthe JF (1976) Organochlorine and mercury residues in the harp seal (Pagophilus groenlandicus). Sci Total Environ 5: 181-195

Julshamn K, Grahl-Nielsen O (2000) Trace element levels in harp seal (Pagophilus groenlandicus) and hooded seal (Cystophora cristata) from the Greenland Sea. A multivariate approach. Sci Total Environ 250:123-133

Law RJ, Morris RJ, Allchin CR, Jones BR, Nicholson MD (2003) Metals and organochlorines in small cetaceans stranded on the east coast of Australia. Mar Pollut Bull 46: $1200-1211$

Moreno VJ, Pérez A, Bastida R, de Moreno JEA, Malaspina AM (1984) Distribución de mercurio total en los tejidos de un delfín nariz de botella (Tursiops gephyreus, Lahille, 1908) de la provincia de Buenos Aires (Argentina). Rev Invest Des Pesq 4:93-102

> Naya DE, Arim M, Vargas R (2002) Diet of South American fur seals (Arctocephalus australis) in Isla de Lobos, Uruguay. Mar Mamm Sci 18:734-745

Ponce de León A, Pin OD (2006) Distribución, reproducción y alimentación del lobo fino Arctocephalus australis y del león marino Otaria flavescens en Uruguay. In: Menafra R, Rodríguez-Gallego L, Scarabino F, Conde D (eds) Bases para la conservación y el manejo de la costa uruguaya. Vida Silvestre Uruguay, Montevideo, p 305-313

Rodríguez DH (1996) Biología y Ecología de los Pinípedos del sector bonaerense. Tesis Doctoral en Ciencias Biológicas, Universidad Nacional de Mar del Plata, Mar del Plata 
Rodríguez D, Rivero L, Bastida R (2002) Feeding ecology of the Franciscana (Pontoporia blainvillei) in marine and estuarine waters of Argentina. Latin Am J Aquat Mamm 1: 77-94

Storelli MM, Storelli A, Giacominelli-Stuffer R, Marcotrigiano GO (2004) Mercury speciation in the muscle of two commercially important fish, hake (Merluccius merluccius) and striped mullet (Mullus barbatus) from the Mediterranean Sea: estimated weak intake. J Agric Food Chem 52:1130-1147

Túnez JI, Centrón D, Cappozzo HL, Cassini MH (2007) Geographic distribution and diversity of mitochondrial DNA haplotypes in South American sea lions (Otaria flave-

Editorial responsibility: Hans Heinrich Janssen, Oldendorf/Luhe, Germany scens) and fur seals (Arctocephalus australis). Mamm Biol 72:193-203

Vaz-Ferreira R, Ponce de León A (1987) South American fur seal, Arctocephalus australis, in Uruguay. In: Croxall JP, Gentry RL (eds) Status, biology and ecology of fur seals. NOAA Tech Rep 51:29-32

Wagemann R, Stewart REA, Lockhart WL, Stewart BE, Povoledo M (1988) Trace metals and methylmercury: associations and transfer in harp seal (Phoca groenlandica) mother and their pups. Mar Mamm Sci 4:339-355

Wolfe ME, Schwarzbach S, Sulaiman RA (1998) Effects of mercury on wildlife: a comprehensive review. Environ Toxicol Chem 17:146-160

Submitted: June 19, 2008; Accepted: October 23, 2008 Proofs received from author(s): January 19, 2009 